\title{
The Automobile as a Central Symbol in F. Scott Fitzgerald
}

\author{
Luis Girón Echevarría \\ Universidad de Extremadura
}

"When I was a boy," F. Scott Fitzgerald wrote, "I dreamed that I sat always at the wheel of a magnificent Stutz, a Stutz as low as a snake and as red as an Indiana barn."1 Fitzgerald would have to wait until 1931 to sit beside the wheel of his own Stutz, but by then he was no longer young, but middle-aged; the car was not new, but second-hand; and it was not red but blue.

"Begin to feel lack of automobile,"2 reads Fitzgerald's Ledger for July 1912, when Scott was only fifteen. Throughout the life of the Ledger, in numerous entries, Fitzgerald records his automotive history: "car troubles," "sold car," "bought car," "car freezing," "car broken," "car busted," etc. The cars in Fitzgerald's life provide a rough gauge by which to measure the discrepancy between the dream and reality of his life, as well as his waning fortunes, and his journey from careless, irresponsible youth to cautious, worried middle-age. In 1932 he remembered "buying magnificent but broken-down cars." 3 His first car, purchased in 1920 after the publication of his best-selling first novel, This Side of Paradise, was a three-year old sports coupé; during the next two decades he would own a used Rolls Royce, an old Buick, the aforementioned Stutz, a nine-year-old Packard, an old 1934 Ford coupé, and, finally, a second-hand 1937 Ford convertible.

The automobile and the dream girl are inextricably linked in Fitzgerald's fiction. Fifteen-year old Basil Duke Lee in "A Night at the Fair" is fascinated by the sight of "a small car, red in color and slung at that proximity to the ground which indicated both speed of motion and speed of life":

It was a Black Wildcat, and for the next five years it represented the ambition of several million American boys. Occupying it, in the posture of aloof exhaustion exacted by the sloping seat, was a blonde, gay, baby-faced girl. ${ }^{4}$

Basil knows that the owner of the car, Speed Paxton, is "dimly terrible"; nevertheless, he envies him as he rides "off into the sunset in such a chariot, into the very hush and mystery of night, beside him the mystery of that baby-faced girl.",

Dexter Green in "Winter Dreams" and Jay Gatsby in The Great Gatsby see a promise of happiness in the faces of their dream girls, Judy Jones and Daisy Fay. But in the beginning neither one has a "chariot" to facilitate his romantic pursuit; both dream girls, 
however, have automobiles of their own, a fact that underscores their elusiveness, as well as the economic mismatch. Daisy drives a little white roadster; Judy, a roadster in which she takes Dexter to a picnic supper, but after supper she disappears, "likewise in her roadster, with another man." 6

Nearly every young woman pursued by a Fitzgerald hero is associated with an automobile, prestigious or otherwise. Isabelle in This Side of Paradise dates boys who are "terrible speeds" and drive "alluring red Stutzes." Nicole in Tender is the Night arrives at the half-moon entrance of the Palace Hotel in "a magnificent Rolls" of gigantic proportions. ${ }^{8}$ Kathleen, in The Last Tycoon, drives a jalopy, a Chevy "which would have brought eighty dollars from any kindly dealer." Some of the dream girls even make their entrances via the automobile. In "On Schedule," René catches his first glimpse of Becky Snyder's beauty "peering over the back of a cut-down flivver stalled on the Lincoln Highway." In "The Smilers" Sylvester encounters his ex-dream girl. Betty Tearle, "sitting in her chauffeured machine in front of Tiffany's on Fifth Avenue." 11

"Once, in the years before the First World War," writes Stephen Sears in The Automobile in America, "ownership of any kind of an automobile was regarded as the American dream come true." But the decade that followed, "The dream was amended to mean ownership of the 'right' kind of car, symbolic of the 'right' social status." 12 Sinclair Lewis wrote in his novel Babbitt:

In the city of Zenith, in the barbarous twentieth century, a family's motor car indicated its social rank as precisely as the grades of the peerage determined to the rank of an English family... There was no court to decide whether the second son of a Pierce Arrow limousine should go in to dinner before the first son of a Buick roadster, but of their respective social importance there was no doubt. ${ }^{13}$

Fitzgerald, of course, was not blind to this social phenomenon, to the wealth that rolls by in limousines, and his fiction is dotted with the names and descriptions of automobiles, real or otherwise.$^{14}$ For Fitzgerald-both in fiction and real life-the automobile was the ultimate status symbol; it gave proof of one's location on the road to social and financial success. In the very expensive category there is Gatsby's Rolls Royce, driven by a chauffeur in a robin's-egg blue uniform. In his comic satire on the American Dream, "The Diamond as Big as the Ritz," Fitzgerald combines the names of two of the most expensive luxury cars of his time-the Rolls Royce and the Pierce-to convey the penchant of America's economic élite for conspicuous consumption: "St. Midas' School is half an hour from Boston in a Rolls-Pierce motor-car," Fitzgerald wrote.

Fitzgerald, ever the social historian, was keenly attuned to the social distinctions generated by the possession of the 'right' automobile. In The Beautiful and the Damned Anthony Patch observes that "all the newest and most beautiful design in automobiles were out on Fifth Avenue," but when it comes to buy one of his own, he purchases a cheap new roadster, which he later refers to with contempt as "a farmer's car." 15 Fitzgerald's protagonists of all ages are keenly aware of the social statements that their cars convey. 
It is puzzling there are so few references to the Model T Ford in Fitzgerald's fiction. As Stephen Sears explains, "Those reaching up for a handhold on the social ladder in the Roaring Twenties grew self conscious about driving a Model $T$, the same make that farmers with manure on their boots drove into town every Saturday afternoon." 16 John Steinbeck wrote in Cannery Row, "Two generations of Americans knew more about the [Model T] Ford coil than the clitoris, about the planetary system of gears than the solar system of stars." ${ }^{\prime 17}$ Fitzgerald never refers to the Model $T$ by name in his fiction, but there is a handful of references which help to identify this model. In The Great Gatsby, for example, the only car to be seen in George Wilson's garage is "the dust-covered wreck of a Ford." 18 Because the novel is set in 1922, the car most likely is a Model T, for that is the only model Ford manufactured during the previous fourteen years. The "farmer's flivver" that Anthony Patch sees in The Beautiful and the Damned ${ }^{19}$ is unquestionably a Model T. "Flivver" in today"s usage refers to any small, inexpensive car, but originally, dictionaries of slang tell us, it referred only to the Model $\mathrm{T}^{20}$ In his stories written during the Roaring Twenties, Fitzgerald scoffs at the flivver and those who drive it. In "The Jelly Bean," it is a "silly little flivver", ${ }^{21}$ in "Myra Meets His Family," it is a "battered old flivver" driven by a "very dirty, dilapidated man." the automobile. It is variously "stubborn," "sullen," "snorting"; at times it slides "along on tiptoe." 23 In The Great Gatsby Nick notices the "throbbing taxicabs" bound for the theatre district, and later becomes aware of the automobiles that turn "expectantly" into Gatsby's drive, only to describe a darkened house, and then drive "sulkily away." 24 These personifications appear early and late in Fitzgerald's fiction, but they are not characteristic of, nor very important to, his portrayal of the automobile.

Fitzgerald makes extensive use of the automotive metaphor and symbol. In a brief piece of autobiographical fiction found in the Notebooks, for example, he characterizes his life with his wife, Zelda, during the early years of the Jazz Age, as a reckless motor ride:

They rode through five years in open car with the sun on their foreheads and their hair flying. They waved to people they knew but seldom stopped to ask a direction or check on the fuel, for every morning there was a gorgeous new horizon and it was blissfully certain that they would find each other there at twilight. They missed collisions by inches, wavered on the edge of precipices and skidded across tracks to the sound of the warning bell. Their friends tired of waiting for the smash and grew to accept them as sempiternal, forever new as Michael's last idea or the gloss on Amanda's hair. One could almost name the day when the car began to splutter and slow up. ... ${ }^{25}$

Near the end of Tender is the Night, the automotive metaphor is used to describe the change that is taking place in Nicole, her transformation from a young woman psychologically dependent upon her husband to one who is rediscovering her sense of independence and freedom. "The new state of things," she muses, "would be no more than if a racing chassis, concealed for years under the body of a family limousine, should be stripped to its original self. Nicole could feel the fresh breeze already. ..."26 In The Great Gatsby Fitzgerald, in swift strokes, captures the impact of the automobile on the physical and cultural landscape, as well as on the sensibilities. On his drive home to West 
Egg, Nick Carraway observes that "it was deep summer on roadhouse roofs and in front of wayside garages, where new red gas-pumps sat out in pools of light"; and later he admits that he was beginning to like New York, "the racy, adventurous feel of it at night, and the satisfaction that the constant flicker of men and women and machines gives to the restless eye." 27 Thus, it is not surprising to find that the automotive symbol and metaphor are used extensively in The Great Gatsby. Nick, who is not in the same financial bracket as Tom Buchanan or Jay Gatsby, drives an old Dodge. Nick's car, then, may be seen as analogous to his character and his moral values: reliable and old-fashioned. Jordan sees her relationship with Nick in automotive terms and likens their breakup to a collision between two careless drivers. The auto accidents, or near-accidents, in the novel-Daisy's hit-and run, Jordan's near miss of a workman, and the accident of the drunken guest who drives into a ditch fifty feet from Gatsby's door and Tom Buchanan's outside of Santa Barbara-all convey the carelessness, recklessness, and irresponsibility of the times, as well as of the individuals immediately involved. But the most interesting symbol of all is Gatsby's "splendid," "gorgeous" car:

It was a rich cream color, bright with nickel, swollen here and there in its monstrous length with triumphant hat-boxes and supper-boxes and tool-boxes, and terraced with a labyrinth of wind-shields that mirrored a dozen suns. Sitting down behind many layers of glass in a sort of green leather conservatory, we started to town. ${ }^{28}$

The colors of Gatsby's car-cream exterior (two witnesses of the accident describe it as "yellow") and green upholstery - together suggest fulfillment of Gatsby's dream. Green is the color of promise, and in a memorable night scene Gatsby stretches out his arms toward the dark water, toward a single green light that burns at the end of Daisy's dock. Yellow is the color of the gold that Gatsby thought he needed to purchase his dream. Moreover, "cream"- -the adjective that discriminating Nick uses to describe the car, and a color that the dictionary defines as "pale yellow to yellowish white-is a blend of the two colors most frequently associated with the lovers, Daisy's white and Gatsby's gold or yellow.

The automobile has a starring role in "The Family Bus," a short story written in 1933 while Fitzgerald was still in possession of his venerable Stutz. In fact, in no other Fitzgerald story is the automobile such an integral part of the narrative. The story opens with a description of the "fresh from the factory" 1914 model: "It was of an expensive make, low-slung for that period, with electric lights and a self-starter. ..."29 At first glance the expensive, new car seems only to symbolize the financial and social status of the Hendersons, who live in "baronial splendor." But Fitzgerald, as though to foreshadow the complexity of its role, tells us that the car appears "like several cars each on a slightly different level." ${ }^{30}$ The automobile clearly serves to point up the central theme of the story: the social and economic mobility of American society. The Hendersons' fortunes decline over the years: after the death of her husband, Mrs. Henderson no longer can maintain a chauffeur nor can she afford to send her son to college. But the Hendersons' former gardener has risen dramatically in the world: he now lives with his family in the 
big Dutch colonial house, employs a chauffeur, and sends his young daughter, Jannekin, to Europe to be "fashionably educated."

In Fitzgerald's fiction, the automobile is also used to convey the shattered dream. The future is full of promise for Dick Humbird, the idealized "aristocratic" youth in This Side of Paradise. But in a careless, drunken moment, his car is snuffed out in a car wreck. In The Great Gatsby, George Wilson's tattered dreams of a good life and a happy marriage are symbolized by "the dust-covered wreck of a Ford" in his garage. Like the car, Wilson is "spiritless," his suit and hair covered with ashen dust.

Automobiles were Fitzgerald's only major possessions-he never owned a home of his own-and they weave in and out of his life, his Notebooks, his essays, his letters, his Ledger, and his fiction. In fact, it would be difficult to conceive of the Jazz Age, or the fiction of F. Scott Fitzgerald, without the automobile. The limousines, roadsters, and jalopies provided an authentic backdrop to his portrait of the restless Jazz Age and the disillusioned decade that followed. At times in his fiction the automobile serves importantly as symbol or metaphor, occassionally so closely associated with the aspirations of his hero or heroine that it becomes an embodiment of the dream itself-and its very denial. It was Fitzgerald's destiny to begin life dreaming of a magnificent red Stutz Bearcat and to end up driving a second-hand Ford. But during the interval he wrote of America's dreams and of America's enduring love affair with the automobile.

\section{Notes}

1. The Notebooks of F. Scott Fitzgerald, ed. Matthew Bruccoli (New York: Harcourt Brace Jovanovich/Bruccoli Clark, 1978), pp. 244-45.

2. F. Scott Fitzgerald's Ledger, ed. Matthew J. Bruccoli (Washington: Bruccoli Clark, 1973), p. 166.

3. F. Scott Fitzgerald, The Crack-Up, ed. Edmund Wilson (New York: New Directions, 1945), p. 28.

4. F. Scott Fitzgerald, Afternoon of an Author, ed. Arthur Mizener (New York: Scribner's, 1958), p. 16.

5. Ibid., p. 17.

6. F. Scott Fitzgerald, All the Sad Young Men (New York: Scribner's, 1926). The term "roadster" appears frequently in Fitzgerald's fiction. The term was used by the automotive industry from 1920 to 1940 to describe a two-seater open car of sporty appearance.

7. F. Scott Fitzgerald, This Side of Paradise (New York: Scribner's, 1920), p. 67.

8. F. Scott Fitzgerald, Tender is the Night (New York: Scribner's, 1934), p. 145.

9. F. Scott Fitzgerald, The Last Tycoon (New York: Scribner's, 1941), p. 77.

10. The Price Was High: The Last Uncollected Stories of F. Scott Fitzgerald, ed. Matthew J. Bruccoli (New York: Harcourt Brace Jovanovich/Bruccoli Clark, 1979), p. 441.

11. Ibid., p. 4.

12. Stephen W. Sears, The Automobile in America (New York: American Heritage, 1977), p. 213.

13. Sinclair Lewis, Babbitt (New York: Harcourt, Brace, 1922), pp. 74-75. 
14. In his fiction Fitzgerald quite often used the names of real cars: Locomobile, PierceArrow, Rolls Royce, and Chevy. On at least two occasions he invented the names: The RollsPierce in "A Diamond as Big as the Ritz," and the Blatz Wildcat in "A Night at the Fair."

15. F. Scott Fitzgerald, The Beautiful and the Damned (New York: Scribner's, 1922), pp. 124,174 , and 210.

16. Stephen W. Sears, op. cit., p. 212.

17. John Steinbeck, Cannery Row (New York: Viking, 1945), p. 60.

18. F. Scott Fitzgerald, The Great Gatsby (New York: Scribner's, 1925), p. 25.

19. Fitzgerald, The Beautiful and the Damned, p. 217.

20. See New Dictionary of American Slang, ed. Robert L. Chapman (New York: Harper \& Row, 1986) and Dictionary of American Slang, eds. Harold Wentworth and Stuart Berg Flexner (New York: Thomas V. Crowell, 1967).

21. F. Scott Fitzgerald, Tales of the Jazz Age (New York: Scribner's, 1922), p. 18.

22. The Price Was High, pp. 16 and 15.

23. The Price Was High, p. 330; The Last Tycoon, p. 86; and The Price Was High, pp. 15 and 548.

24. Fitzgerald, The Great Gatsby, pp. 57 and 113.

25. The Notebcoks of F. Scott Fitzgerald, p. 87.

26. Tender is the Night, p. 280.

27. The Great Gatsby, pp. 21 and 57.

28. Ibid., p. 64.

29. The Price Was High, p. 488.

30. Ibid., p. 489. 